\title{
A Reassessment of the Species Concept in Eutypa lata, the Causal Agent of Eutypa Dieback of Grapevine
}

\author{
P. E. Rolshausen, N. E. Mahoney, R. J. Molyneux, and W. D. Gubler
}

First and fourth authors: University of California-Davis, Department of Plant Pathology, One Shields Avenue, Davis 95616; and second and third authors: U.S. Department of Agriculture (USDA), Albany, Berkeley, CA and Western Regional Research Center, USDA-Agricultural Research Service, 800 Buchanan Street, Albany, Berkeley, CA. Accepted for publication 21 October 2005.

\begin{abstract}
Rolshausen, P. E., Mahoney, N. E., Molyneux, R. J., and Gubler, W. D. 2006. A reassessment of the species concept in Eutypa lata, the causal agent of Eutypa dieback of grapevine. Phytopathology 96:369-377.

Eutypa dieback is a vascular disease of several cultivated crops and trees worldwide. The attribution of the name to the agent responsible for branch dieback is ambiguous. Pathogenicity of Eutypa sp. first was reported on apricot and the causal agent was named E. armeniacae. However, no morphological differences were reported with the previously described E. lata, and some authors considered both species synonymous. Others regarded them as distinct species on the basis of pathogenesis and

and $\beta$-tubulin gene. These analyses included several other taxa placed in the same family (Diatrypaceae), and yielded three groups. The isolates referred to as E. lata in previous work clustered with Diatrype stigma in one group. Isolates of E. armeniacae and E. lata clustered in a second group, supporting the synonymy of these species. The third group included other Eutypa spp. supporting the polyphyletic origin of this genus. Measurements of conidia length and secondary metabolite production of isolates supported the phylogenetic analyses. Secondary metabolites appeared to be a synapomorphic character shared by several taxa including E. lata, E. armeniacae, E. laevata, and E. petrakii var. petrakii.
\end{abstract} molecular analysis. We further investigated the relatedness of both species by phylogenetic analyses of the internal transcribed spacer region

Eutypa lata (Pers.:Fr.) Tul. \& C. Tul. (= E. armeniacae Hansf. $\&$ M. V. Carter) is a pathogen of woody plants worldwide (7) and is responsible for significant economic damage to the wine industry (37) by reducing vegetative growth and fruit yields (26). The anamorph and teleomorph of the fungus are produced on dead wood, but conidia do not play a role in the epidemiology of the disease. The pathogen is disseminated by ascospores $(29,30)$, which infect wounds and slowly kill its hosts by producing an array of enzymes $(11,36)$ and secondary metabolites (19-21,23, $39,40)$.

The genus Eutypa (Ascomycetes, Xylariales, Diatrypaceae) was first established by Tulasne and Tulasne (44). However, E. lata originally was based on Persoon's (31) morphological description of Sphaeria lata fruiting bodies found on five woody plant species (Acer sp., Prunus sp., Lonicera sp., Cratageus sp., and Tilia sp.). However, these specimens deposited at Persoon's herbarium in Leiden are now lacking identifiable morphological characters and Rappaz (32) designated a neotype of E. lata from Acer sp., Tilia sp., Cratageus sp., and Lonicera xylosteum, with published descriptions of the anamorph and teleomorph (33), and deposited its collection at the Centraalbureau voor Schimmelcultures (CBS, Utrecht, The Netherlands). However, no information concerning the pathogenicity of these isolates was reported.

Pathogenicity of a Eutypa sp. first was observed on apricot (Prunus armeniaca L.) and the name E. armeniacae Hansf. \& M. V. Carter was given to the agent responsible for branch dieback (4). No morphological features of the anamorph or teleomorph could differentiate E. lata from E. armeniacae $(16,17,32,33)$, and the species later were regarded as synonymous (33). However,

Corresponding author: P. E. Rolshausen; E-mail address: perolshausen@ucdavis.edu

DOI: 10.1094/PHYTO-96-0369

(c) 2006 The American Phytopathological Society
Additional keywords: vegetative compatibility groups, Xylariales.

some authors regarded E. armeniacae as an appropriate designation for pathogenic strains (22). DeScenzo et al. (9) separated $E$. lata and E. armeniacae based on sequence analysis of ribosomal DNA and amplified fragment length polymorphism (AFLP) patterns. They concluded that E. armeniacae was present on cultivated crops, whereas E. lata was present on the native Californian plant hosts valley oak (Quercus lobata) and madrone (Arbutus menziesii) and also on grapevine (Vitis vinifera L.), and that both species were pathogenic on their hosts. However, the molecular analysis of isolates of their collection did not include additional referable diatrypaceous specimens and, therefore, the grouping of their isolates could not be compared with related species classified in this family. Moreover, morphological identification of taxa in the family Diatrypaceae is often problematic $(16,17,33,35)$, and misnaming of isolates is possible.

Molecular markers have provided a new tool for delimitation of fungal taxa that traditionally were identified based on morphological species concepts (3). Biochemical data also have proven to be useful in the circumscription of species in certain groups of fungi $(2,25,27,45)$. In the present study, phylogenetic analysis of the internal transcribed spacer (ITS) region, $\beta$-tubulin gene, and combined data sets were used in combination with morphological data (conidia length) and biochemical data (secondary metabolite profiles) of several diatrypaceous fungi to determine whether or not E. lata and E. armeniacae are distinct species.

\section{MATERIALS AND METHODS}

Fungal collection. A collection of 46 fungal isolates representing 15 species of the family Diatrypaceae (Eutypella vitis (Schwein.:Fr.) Ellis \& Everth., Diatrypella sp., Diatrype bullata (Hoffm.:Fr.) Fr., D. stigma (Hoffm.:Fr.) Fr., D. flavovirens (Pers.:Fr.) Fr., Eutypa lejoplaca (Fr.:Fr.) Fuckel, E. maura (Fr.:Fr.) Fuckel, E. astroidea (Fr.:Fr.) Rappaz, E. crustata (Fr.:Fr.) Sacc., 
E. leptoplaca Rappaz, E. tetragona (Duby) Sacc., E. petrakii Rappaz, E. laevata (Nitschke) Sacc., E. armeniacae, and E. lata) was established at the University of California, Davis (UC Davis) (Table 1). Five isolates of E. lata were recovered from wood canker by classical isolation techniques. Seven isolates of Diatrypella sp. (one isolate), Diatrype stigma (one isolate), D. bullata (one isolate), and E. lata (four isolates) were cultured from ascospores obtained as described by Carter (5) and germinated on water-agar medium. A single hyphal tip was transferred to potato dextrose agar (PDA) plates in order to obtain a pure culture of each isolate. Isolates recovered from ascospores were identified based on morphological features of the teleomorph $(17,33)$.
E. lata isolates recovered from wood cankers were identified by polymerase chain reaction (PCR) restriction fragment length polymorphism (RFLP) patterns because of the paucity of identifiable morphological characters (35). The remaining 34 isolates were received from other culture collections (Table 1) and were named as identified by their source. E. armeniacae isolate 28120 from the American Type Culture Collection (ATCC; VA) was used by DeScenzo et al. (9) as reference for support of the E. armeniacae clade in their study. The collection received from E. \& J. Gallo Winery Culture Collection (Modesto, CA) also included the group of eight isolates (E177.OK, E178.OK, E179.OK, E180.OK, E247.MD, E252.MD, E253.MD, and

TABLE 1. Species, identification number (ID), source, origin, and host of fungal taxa used for phylogenetic analyses, with GenBank accession numbers

\begin{tabular}{|c|c|c|c|c|c|c|}
\hline \multirow[b]{2}{*}{ Isolate ID ${ }^{\mathrm{a}}$} & \multirow[b]{2}{*}{ Source ${ }^{b}$} & \multirow[b]{2}{*}{ Fungal species ${ }^{\mathrm{c}}$} & \multirow[b]{2}{*}{ Host } & \multirow[b]{2}{*}{ Origin } & \multicolumn{2}{|c|}{ GenBank accession number } \\
\hline & & & & & ITS $^{d}$ & $\beta$-Tubulin \\
\hline 64171 & ATCC & Eutypella vitis & Vitis labrusca & Illinois, United States & AJ302466 & $\ldots$ \\
\hline ELM13 $13^{\text {myc }}$ & MSU & Eutypella vitis & Vitis vinifera & Michigan, United States & DQ006943 & DQ006999 \\
\hline 215.87 & CBS & Diatrype bullata & Salix sp. & Switzerland & AJ302422 & $\ldots$ \\
\hline DCh400per & UCD & Diatrype bullata & Salix lasiolepsis & California, United States & DQ006946 & DQ007002 \\
\hline 205.87 & CBS & Diatrype disciformis & Fagus sylvatica & Switzerland & AJ302437 & $\ldots$ \\
\hline 211.87 & CBS & Diatrype stigma & Quercus sp. & Ireland & AJ302438 & $\ldots$ \\
\hline DCash200per & $\mathrm{UCD}$ & Diatrype stigma & Quercus sp. & California, United States & DQ006945 & DQ007003 \\
\hline $272.87^{\mathrm{myc}}$ & CBS & Diatrype flavovirens & Quercus ilex & France & AJ302457 & DQ006959 \\
\hline F-093,582 & J. Checa & Diatrype flavovirens & Eucalyptus globulus & Spain & AJ302430 & $\ldots$ \\
\hline 52484 & ATCC & Diatrypella frostii & Acer sp. & Unknown & AJ302441 & $\ldots$ \\
\hline DHb500per & UCD & Diatrypella sp. & Vitis vinifera & California, United States & DQ006947 & DQ007001 \\
\hline $248.87^{\mathrm{myc}}$ & CBS & Eutypa lejoplaca & Acer pseudoplatanus & Switzerland & DQ006922 & DQ006974 \\
\hline $219.87^{\text {myc }}$ & CBS & Eutypa maura & Acer pseudoplatanus & Switzerland & DQ006926 & DQ006967 \\
\hline $292.87^{\text {myc }}$ & CBS & Eutypa astroidea & Fraxinus excelsior & Switzerland & AJ302458 & DQ006966 \\
\hline $210.87^{\text {myc }}$ & CBS & Eutypa crustata & Ulmus sp. & France & AJ302448 & DQ006968 \\
\hline $287.87^{\mathrm{myc}}$ & CBS & Eutypa leptolaca & Frangula alnus & Switzerland & DQ006924 & DQ006961 \\
\hline $286.87^{\text {myc }}$ & CBS & Eutypa leptolaca & Arundo donax & France & AJ302453 & DQ006963 \\
\hline $284.87^{\mathrm{myc}}$ & CBS & Eutypa tetragona & Sarothamnus scoparius & France & DQ006923 & DQ006960 \\
\hline $244.87^{\text {myc }}$ & CBS & Eutypa petrakii var. petrakii & Prunus spinosa & Switzerland & AJ302455 & DQ006958 \\
\hline $245.87^{\mathrm{myc}}$ & CBS & Eutypa petrakii var. petrakii & Salix borealis & Normay & AJ302456 & DQ006970 \\
\hline $291.87^{\text {myc }}$ & CBS & Eutypa laevata & Salix sp. & Switzerland & AJ302449 & DQ006962 \\
\hline $622.84^{\text {myc }}$ & CBS & Eutypa armeniacae & Vitis vinifera & Italy & AJ302446 & DQ006964 \\
\hline $28120^{\text {myc }}$ & ATCC & Eutypa armeniacae & Prunus armeniaca & Australia & DQ006948 & DQ006975 \\
\hline $290.87^{\text {myc }}$ & CBS & Eutypa lata var. aceri & Acer pseudoplatanus & Switzerland & DQ006925 & DQ006965 \\
\hline $217.87^{\text {myc }}$ & CBS & Eutypa lata var. aceri & Acer campestre & France & AJ302451 & DQ006970 \\
\hline $208.87^{\text {myc }}$ & CBS & Eutypa lata & Tilia sp. & Switzerland & DQ006927 & DQ006969 \\
\hline $289.87^{\text {myc }}$ & CBS & Eutypa lata & Cratageus sp. & France & DQ006928 & DQ006973 \\
\hline $247.87^{\text {myc }}$ & CBS & Eutypa lata & Lonicera xylosteum & Switzerland & AJ302459 & DQ006972 \\
\hline $8 \mathrm{D}^{\text {myc }}$ & INRA & Eutypa lata & Vitis vinifera & France & DQ006930 & DQ006986 \\
\hline $\mathrm{ESm}^{\text {per }}$ & Maurice Carter & Eutypa lata & Shinus molle & Australia & DQ006942 & DQ006998 \\
\hline EA1 ${ }^{\text {per }}$ & Maurice Carter & Eutypa lata & Vitis vinifera & Australia & DQ006937 & DQ006994 \\
\hline ESwer & Adrian Bolay & Eutypa lata & Vitis vinifera & Switzerland & DQ006941 & DQ006987 \\
\hline MD1 $1^{\text {myc }}$ & IPV & Eutypa lata & Unknown & Italy & DQ006929 & DQ006985 \\
\hline $1776^{\text {myc }}$ & WRP & Eutypa lata & Vitis vinifera & Australia & DQ006936 & DQ006993 \\
\hline E201 ${ }^{\text {myc }}$ & WRP & Eutypa lata & Vitis vinifera & Australia & DQ006940 & DQ006997 \\
\hline D001 $1^{\mathrm{mc}}$ & WRP & Eutypa lata & Prunus armeniaca & Australia & DQ006938 & DQ006995 \\
\hline G004 $4^{\mathrm{mc}}$ & WRP & Eutypa lata & Prunus armeniaca & Australia & DQ006939 & DQ006996 \\
\hline E117.NYmyc & E. \& J. Gallo & Eutypa lata & Vitis vinifera & New York, United States & DQ006949 & DQ006976 \\
\hline $\mathrm{E} 177 . \mathrm{OK}^{\mathrm{myc}}$ & E. \& J. Gallo & Eutypa lata & Quercus sp. & California, United States & DQ006950 & DQ006977 \\
\hline $\mathrm{E} 178 . \mathrm{OK}^{\mathrm{myc}}$ & E. \& J. Gallo & Eutypa lata & Quercus sp. & California, United States & DQ006951 & DQ006978 \\
\hline $\mathrm{E} 179 . \mathrm{OK}^{\mathrm{myc}}$ & E. \& J. Gallo & Eutypa lata & Quercus sp. & California, United States & DQ006952 & DQ006979 \\
\hline $\mathrm{E} 180 . \mathrm{OK}^{\mathrm{myc}}$ & E. \& J. Gallo & Eutypa lata & Quercus sp. & California, United States & DQ006953 & DQ006980 \\
\hline E247.MD ${ }^{\text {myc }}$ & E. \& J. Gallo & Eutypa lata & Arbutus menziesii & California, United States & DQ006954 & DQ006981 \\
\hline E252.MD $\mathrm{MDc}^{\mathrm{myc}}$ & E. \& J. Gallo & Eutypa lata & Arbutus menziesii & California, United States & DQ006955 & DQ006982 \\
\hline E253.MD ${ }^{\text {myc }}$ & E. \& J. Gallo & Eutypa lata & Arbutus menziesii & California, United States & DQ006956 & DQ006983 \\
\hline E256.GR ${ }^{\text {myc }}$ & E. \& J. Gallo & Eutypa lata & Vitis vinifera & California, United States & DQ006957 & DQ006984 \\
\hline E30 & UCD & Eutypa lata & Vitis vinifera & California, United States & DQ006934 & DQ006991 \\
\hline E7per & UCD & Eutypa lata & Vitis vinifera & California, United States & DQ006944 & DQ007000 \\
\hline E38 $8^{\text {can }}$ & UCD & Eutypa lata & Vitis vinifera & California, United States & DQ006935 & DQ006992 \\
\hline E31 $1^{\text {can }}$ & UCD & Eutypa lata & Vitis vinifera & California, United States & DQ006933 & DQ006990 \\
\hline $\mathrm{E} 454^{\mathrm{can}}$ & $\mathrm{UCD}$ & Eutypa lata & Prunus armeniaca & California, United States & DQ006931 & DQ006988 \\
\hline $\mathrm{E} 456^{\mathrm{can}}$ & UCD & Eutypa lata & Prunus armeniaca & California, United States & DQ006932 & DQ006989 \\
\hline
\end{tabular}

a Isolate received as pure mycelium (myc), obtained from perithecia, (per), or recovered from canker (can).

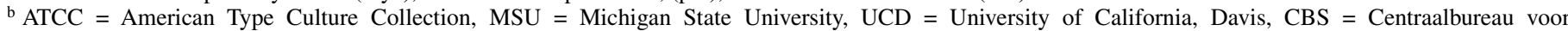
Schimmelcultures, Utrecht, The Netherlands, WRP = Waite Research Precinct, Adelaide, Australia, INRA = Institut National de la Recherche Agronomique, Bordeaux, France, IPV = Instituto di Pathologia Vegetale, Milan, Italy, and E. \& J. Gallo, Modesto, CA.

c Named as identified by their source.

d ITS = internal transcribed spacer. 
E256.GR) found on madrone, oak, and grape in California and referred to as E. lata by DeScenzo et al. (9), and one isolate from grape (E117.NY) that grouped with neither E. lata nor E. armeniacae in their molecular analysis. All isolates were stored on PDA plugs at $4^{\circ} \mathrm{C}$ in sterile water.

Vegetative compatibility test. Isolates of E. lata (Table 1) were tested for vegetative compatibility in order to make sure they were not clones. Isolates were paired in all possible combinations on PDA for 2 weeks at room temperature in the dark. If formation of a barrage was observed, the isolates were placed in different vegetative compatibility groups (VCGs). If no barrage was observed, isolates were placed in the same VCG (15). Isolates also were paired with themselves as a positive control.

DNA extraction and sequencing. Mycelium for DNA extraction was obtained by cutting an agar plug from the outer margin of a growing culture and placing it on a sterile cellophane strip (3 by $3 \mathrm{~cm}$ ) overlaid on PDA. Inoculated plates were incubated at room temperature for 5 days in the dark. Mycelium was scraped off the cellophane, and DNA was extracted as described by Cenis (8). The ITS1/5.8S/ITS2 region and partial coding sequence of the $\beta$-tubulin gene were PCR amplified in both directions in a $50-\mu \mathrm{l}$ reaction as described by Rolshausen et al. (35), using primer pairs ITS1/ITS4 (47) and $\beta \mathrm{t} 2 \mathrm{a} / \beta \mathrm{t} 2 \mathrm{~b}(14)$, respectively. PCR products were checked on a $1 \times$ Tris-borate EDTA $1 \%$ agarose gel, stained with ethidium bromide, and visualized under UV light. PCR products were cleaned using a QIAquick PCR purification kit (Qiagen, Valencia, CA) according to the manufacturer's instructions, and were sequenced with the amplification primers at the DNA sequencing facility on the UC Davis campus.

Phylogenetic analysis. Sequence data were imported into Sequencher (version 4.1; Gene Codes Corporation, MI), in which forward and reverse sequences were aligned and spliced in a consensus sequence. Sequence data of fungal taxa were imported and aligned in ClustalX (41). Sequences were imported into MacClade (version 4.0; Sinauer Associates Inc., Sunderland, MA). Phylogenetic trees were constructed by the maximum parsimony method using the heuristic search algorithm of the Phylogeny Analysis Using Parsimony (PAUP) program (version 4.0b8; Sinauer Associates). Heuristic search was performed with simple addition of sequences and tree bisection-reconnection (TBR) branch swapping. Trees were rooted with Eutypella vitis as the out-group taxon prior to the analysis. All alignments and subse- quent analyses were deposited in TreeBase (accession number S1385). Regions of the ITS1/5.8S/ITS2 sequences that could not be aligned with certainty and generated a high number of parsimonious trees were excluded from the analysis to facilitate tree construction (characters 25-26, 35, 181-182, 426-433, 487$488,500,518-519,548$, and 559). Both complete and truncated matrices of the ITS1/5.8S/ITS2 region are available in TreeBase (matrix accession numbers M2470 and M2472, respectively). The complete sequences of the $\beta$-tubulin gene were used for tree construction (matrix accession number M2471). In all the analyses performed, gaps were treated as missing data and characters had equal weight. Consistency index (CI), homoplasy index (HI), retention index (RI), and tree length were calculated for all trees. Support for internal nodes was assessed by bootstrapping with 1,000 replicates. Sequence identity between taxa was calculated by pairwise comparison. The GenBank taxa Eutypella vitis 64171, Diatrypella frostii 52484, Diatrype bullata 215.87, D. disciformis 205.87, D. stigma 211.87, and D. flavovirens F-093,582 were included only in the phylogenetic analysis of the ITS region because the nucleotide sequences of the $\beta$-tubulin region were not available in the GenBank database. Congruence of the combined ITS and $\beta$-tubulin data set was tested using the partition homogeneity test as implemented in PAUP (13) with 1,000 replicates.

Determination of secondary metabolites produced by fungal isolates. Fungal isolates listed in Table 2 were cultured on PDA medium and a 1-cm plug of agar was drawn from the edge of the growing culture and introduced into a 50-ml grape-based media (19) supplemented with $1 \%$ sucrose. Secondary metabolite production was assessed after 1 month in static culture at room temperature ( 20 to $22^{\circ} \mathrm{C}$ ). The fungal mass was removed from the medium by filtration (Whatman No. 1) and the filtrate partitioned with an equal volume of ethyl ether. The ether was concentrated under reduced pressure and the dried extract dissolved in methanol $(1 \mathrm{ml})$ and filtered through a $0.45-\mu \mathrm{m}$ nylon syringe filter. Aliquots $(20 \mu \mathrm{l})$ were analyzed quantitatively for fungal metabolites by reverse-phase high-performance liquid chromatography (Varian Microsorb 100-5 C18, 250 by $4.6 \mathrm{~mm}$ i.d.) using a mobile phase gradient of $100 \%$ water containing $0.5 \%$ acetic acid to $100 \%$ acetonitrile over $30 \mathrm{~min}$ at a flow of $1 \mathrm{ml} / \mathrm{min}$, with detection at $254 \mathrm{~nm}$ using a photodiode array detector (Agilent 1100) (19). The experiment was repeated twice and taxa were considered as secondary metabolite producers if production of one of

TABLE 2. Secondary metabolites production by fungal taxa used in this study after 1 month of growth in static liquid culture of grape cane extract

\begin{tabular}{|c|c|c|c|c|c|c|}
\hline \multirow[b]{2}{*}{ Fungal specimen $^{\mathrm{a}}$} & \multicolumn{6}{|c|}{ Secondary metabolites $(\mu \mathrm{g} / \mathrm{ml})^{\mathrm{b}}$} \\
\hline & Eutypinol & Eulatachromene & Methoxyeutypinol & Eutypine & Siccayne & Eulatinol \\
\hline Eutypa lata 208.87 & 0.3 & 0.1 & - & - & - & - \\
\hline E. lata 289.87 & 6.5 & 0.2 & 0.2 & - & - & - \\
\hline E. lata E7 & 1 & 0.1 & 0.1 & - & 0.2 & 0.2 \\
\hline E. lata E38 & 0.6 & 0.1 & 0.1 & - & - & - \\
\hline E. lata E31 & 12.7 & 1.2 & 1.9 & $\operatorname{tr}$ & 0.1 & 0.1 \\
\hline E. lata $\mathrm{E} 30$ & 5.7 & 0.1 & 0.2 & - & - & - \\
\hline E. lata $\mathrm{E} 454$ & 1.5 & 0.1 & 0.3 & - & $\operatorname{tr}$ & $\operatorname{tr}$ \\
\hline E. lata $\mathrm{E} 456$ & 6.7 & 0.4 & 0.4 & 0.2 & - & - \\
\hline E. lata EA1 & 2.1 & 0.2 & 0.1 & $\operatorname{tr}$ & - & - \\
\hline E. lata $\mathrm{ESm}$ & 0.3 & - & - & - & - & - \\
\hline E. lata D001 & 7.9 & 0.1 & 1.6 & - & - & - \\
\hline E. lata 8D & 5.8 & 3.2 & 2.3 & - & - & - \\
\hline E. lata $\mathrm{ESw}$ & 0.9 & - & - & - & - & - \\
\hline E. lata MD1 & 30 & 1.6 & 3.7 & 0.2 & - & - \\
\hline E. lata var. aceri 290.87 & 5.6 & 0.3 & tr. & $\operatorname{tr}$ & $\operatorname{tr}$ & - \\
\hline E. armeniacae 622.84 & 11.9 & 0.3 & 0.3 & $\operatorname{tr}$ & - & $\operatorname{tr}$ \\
\hline E. laevata 291.87 & 13.5 & 0.9 & - & - & - & - \\
\hline E. petrakii var. petrakii 244.87 & 40.2 & 1.1 & 2.7 & - & - & - \\
\hline E117.NY & 0.2 & 0.2 & 2.5 & - & - & - \\
\hline
\end{tabular}

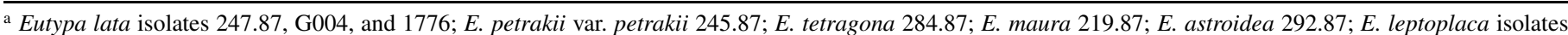
286.87 and 287.87; Diatrype flavovirens 272.87; D. bullata DCh400; Diatrypella sp. DHb500; and Gallo isolates E177.OK, E178.OK, E179.OK, E180.OK, E247.MD, E252.MD, E253.MD, and E256.MD did not produce detectable quantities of the secondary metabolite listed in this table.

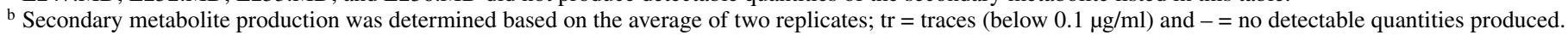


the acetylenic phenol compounds (eutypine, eulatachromene, eulatinol, eutypinol, methyleutypinol, or siccayne) was observed in at least one replication.

Conidia measurement. Fungal isolates listed in Table 3 were cultured on PDA medium. Isolates were placed in the dark at room temperature until conidiomata were produced. Conidiomata were removed from the culture medium and prepared by staining in cotton blue before taking measurements of 30 conidia per isolate under microscope using the software SPOT (version 3.5.2; Technical Instrument San Francisco, Burlingame, CA). Conidia measurements reflected the curved length of the spore.

\section{RESULTS}

Phylogenetic analyses. A heuristic maximum parsimony analysis of the ITS1/5.8S/ITS2 region and partial coding sequence of the $\beta$-tubulin gene yielded a total of 535 (Fig. 1) and 4 (Fig. 2) equally most-parsimonious trees of 307 steps $(\mathrm{CI}=0.603$, $\mathrm{RI}=0.861, \mathrm{HI}=0.397)$ and 404 steps $(\mathrm{CI}=0.624, \mathrm{RI}=0.852$, $\mathrm{HI}=0.376)$, respectively. In all, 540 characters of the ITS region

TABLE 3. Conidia length $(\mu \mathrm{m})$ measured on PDA medium and secondary metabolites produced in liquid culture of grape cane extract of fungal specimens used in this study

\begin{tabular}{|c|c|c|c|}
\hline \multirow[b]{2}{*}{ Fungal specimen } & \multicolumn{2}{|c|}{ Conidia $(\mu \mathrm{m})$} & \multirow[b]{2}{*}{ Prod $^{c}$} \\
\hline & Measured $^{\mathrm{a}}$ & Reported $^{b}$ & \\
\hline Eutypa lata 208.87 & $26.4 \pm 2.3$ & $18-39$ & + \\
\hline E. lata 289.87 & $29.8 \pm 2.6$ & $18-39$ & + \\
\hline E. lata 247.87 & nd & $32-41$ & - \\
\hline E. lata var. aceri 290.87 & $24.8 \pm 2$ & $15-28$ & + \\
\hline E. lata var. aceri 217.87 & $24.3 \pm 2$ & $15-28$ & nd \\
\hline E. armeniacae 28120 & nd & $\ldots$ & + \\
\hline E. armeniacae 622.84 & $25.0 \pm 1.9$ & $\ldots$ & + \\
\hline E. lata $\mathrm{ESm}$ & $30.9 \pm 2.2$ & $\ldots$ & + \\
\hline E. lata $\mathrm{ESw}$ & $29.1 \pm 4.8$ & $\ldots$ & + \\
\hline E. lata E7 & $28.4 \pm 2.3$ & $\ldots$ & + \\
\hline E. lata $\mathrm{E} 454$ & $34.0 \pm 2.8$ & $\ldots$ & + \\
\hline E. lata $\mathrm{E} 456$ & $27.5 \pm 3.2$ & $\ldots$ & + \\
\hline E. lata E31 & $29.5 \pm 3.4$ & $\ldots$ & + \\
\hline E. lata MD1 & $26.3 \pm 2.8$ & $\ldots$ & + \\
\hline E. lata 1776 & $24.8 \pm 2$ & $\ldots$ & - \\
\hline E. lata G004 & nd & $\ldots$ & - \\
\hline E. lata D001 & nd & $\ldots$ & + \\
\hline E. lata EA1 & nd & $\ldots$ & + \\
\hline E. lata 8D & nd & $\ldots$ & + \\
\hline E. lata E38 & nd & $\ldots$ & + \\
\hline E. lata $\mathrm{E} 30$ & nd & $\ldots$ & + \\
\hline E117.NY & $19.4 \pm 3$ & $\ldots$ & + \\
\hline E. laevata 291.87 & nd & $34-55$ & + \\
\hline E. petrakii var. petrakii 244.87 & nd & $24-45$ & + \\
\hline E. petrakii var. petrakii 245.87 & nd & $24-45$ & + \\
\hline E. tetragona 284.87 & nd & $20-37$ & - \\
\hline E. leptoplaca 287.87 & nd & $17-39$ & - \\
\hline E. astroidea 292.87 & nd & $26-43$ & - \\
\hline E. maura 219.87 & nd & $11-20$ & - \\
\hline Diatrype flavovirens 272.87 & nd & $20-31$ & - \\
\hline D. stigma 211.87 & nd & $4.5-7.5$ & nd \\
\hline Gallo E178.OK & $6.6 \pm 0.7$ & $\ldots$ & - \\
\hline Gallo E179.OK & $7.5 \pm 0.5$ & $\ldots$ & - \\
\hline Gallo E180.OK & $7.3 \pm 0.6$ & $\ldots$ & - \\
\hline Gallo E247.MD & $5.9 \pm 0.8$ & $\ldots$ & - \\
\hline Gallo E252.MD & $6.6 \pm 0.7$ & $\ldots$ & - \\
\hline Gallo E253.MD & $6.8 \pm 0.7$ & $\ldots$ & - \\
\hline Gallo E256.GR & $6.2 \pm 0.6$ & $\ldots$ & - \\
\hline D. bullata DCh400 & nd & $15-25$ & - \\
\hline Diatrypella sp. DHb500 & nd & $\ldots$ & - \\
\hline
\end{tabular}

a nd = not determined.

b As reported by Rappaz (33).

c Secondary metabolite production based on results as shown in Table 2: + = production of at least one of the acetylenic phenol compounds (eutypine, eulatachromene, eulatinol, eutypinol, methyleutypinol, or siccayne), - = no detectable quantities of acetylenic phenol compounds produced, and nd = not determined. were used for tree reconstruction, of which 396 were constant, 36 were parsimony uninformative, and 108 were parsimony informative. Of 418 characters derived from the partial coding sequence of the $\beta$-tubulin gene, 249 were constant, 46 were parsimonyuninformative, and 123 were parsimony informative. The combined analysis of both nucleotide sequences yielded 260 most parsimonious trees (Fig. 3) of 723 steps $(\mathrm{CI}=0.609, \mathrm{RI}=0.833$, $\mathrm{HI}=0.391)$. In all, 1,000 characters of the combined regions were used for tree reconstruction, of which 681 were constant, 112 were parsimony uninformative, and 207 were parsimony informative.

D. stigma DCash200 and D. bullata DCh400 showed $100 \%$ nucleotide sequence homology with sequences posted in GenBank (Table 1) of D. bullata 215.87 and D. stigma 211.87, respectively. Diatrypella sp. DHb500 showed $97.7 \%$ sequence homology and $100 \%$ bootstrap support with GenBank isolate of Diatrypella frostii 52484. Thus, phylogenetic analyses of the $\beta$-tubulin and combined data sets of ITS and $\beta$-tubulin could be performed with confidence in order to establish taxonomic affiliation and relationships of fungal taxa classified within the family Diatrypaceae.

Phylogenetic reconstruction of the combined sequences yielded tree topology similar to that for individual ITS and $\beta$-tubulin sequences analyses, with separation of three distinct groups of taxa (Figs. 1, 2, and 3). Partition homogeneity tests demonstrated congruence between the analysis of the two individual data sets $(P=$ 0.068). The analysis of the combined data sets yielded strong support for the three groups, all of which were accorded bootstrap values greater than $95 \%$ (Fig. 3). In all three analyses, Diatrypella sp. and Diatrype flavovirens were excluded from the three groups.

The first group included Diatrype bullata, D. stigma, and the eight Gallo isolates previously referred to as E. lata (9). Within group 1, the clustering of the eight Gallo isolates with D. stigma was strongly supported at a $99 \%$ bootstrap value in the combined data set analysis (Fig. 3).

Group 2 included Eutypa lejoplaca, E. crustata, E. astreoidea, E. maura, E. tetragona, and E. leptoplaca and was strongly supported by bootstrap in all three data set analyses (Figs. 1, 2, and $3)$.

Bootstrap support of group three, that included E. armeniacae, E. laevata, E. petrakii var. petrakii, E. lata, and isolate E117.NY, was $95 \%$ in the combined analysis (Fig. 3), whereas much lower values were obtained in individual analyses (Figs. 1 and 2). Within this group, monophyly of a clade that included the two E. armeniacae isolates and most E. lata isolates was supported with a $99 \%$ bootstrap value. The isolates of this clade showed over $99 \%$ sequence homology in the combined data set. All E. lata isolates of this clade were placed in different VCGs, indicating that they were not clonally related. However, this clade excluded CBS isolates E. lata 289.87 (97.8\% sequence homology) and E. lata var. aceri 217.87 and 290.87 (95.7\% sequence homology). The two E. lata var. aceri isolates grouped together with a $100 \%$ bootstrap support and also shared a common ancestor with E. laevata (96\% bootstrap support). The two isolates of E. petrakii var. petrakii showed $5.3 \%$ heterogeneity between their nucleotide sequences of the combined data set. E. petrakii var. petrakii isolate 245.87 clustered with E117NY with a $56 \%$ bootstrap support, whereas E. petrakii var. petrakii isolate 244.87 did not cluster with any taxon.

Secondary metabolites. Analysis of secondary metabolites indicated that E. lata isolates 208.87, 289.87, ESm, ESw, E7, E454, E456, E31, MD1, D001, EA1, 8D, E38, and E30; E. lata var. aceri 290.87; E. armeniacae 622.84; E. laevata 291.87; E. petrakii var. petrakii isolates 244.87 and 245.87; and one Gallo isolate, E117.NY, produced at least one of the following compounds: eutypine, eulatachromene, eulatinol, eutypinol, methyleutypinol, or siccayne (Table 2). Eutypinol, methyleutypinol, and eulatachromene were the most widely distributed and abundant metabolites among strains, whereas eutypine, siccayne, and eulati- 
nol occasionally were produced in small amounts by fungal isolates. The eight Gallo isolates E177.OK, E178.OK, E179.OK, E180.OK, E247.MD, E252.MD, E253.MD, and E256.GR; E. lata isolates 247.87, 1776, and G004; E. tetragona 284.87; E. leptoplaca 287.87 ; E. astroidea 292.87 ; E. maura 219.87 ; D. flavovirens 272.87; D. bullata DCh400; and Diatrypella sp. DHb500 did not produce detectable quantities of these secondary metabolites.

Conidia length. The lengths of conidia of $E$. lata isolates 208.87 and 289.87 were measured at $26.4 \pm 2.3$ and $29.8 \pm 2.6 \mu \mathrm{m}$, respectively, and were in accordance with the measurements of the same isolates made by Rappaz (33) and presented in Table 3. Likewise, E. lata isolates ESm, ESw, E7, E454, E456, E31, MD1, and 1776 ranged from $24.8 \pm 2$ to $34 \pm 2.8 \mu \mathrm{m}$ (Table 3). E. lata var. aceri isolates 290.87 and 217.87 were measured at $24.8 \pm 2$ and $24.3 \pm 2 \mu \mathrm{m}$, respectively, which was in accordance with the measurements made by F. Rappaz for the same isolates (33). The conidia length of $E$. armeniacae 622.84 was measured at $25 \pm$ $1.9 \mu \mathrm{m}$. The eight Gallo isolates (E177.OK, E178.OK, E179.OK, E180.OK, E247.MD, E252.MD, E253.MD, and E256.GR) had

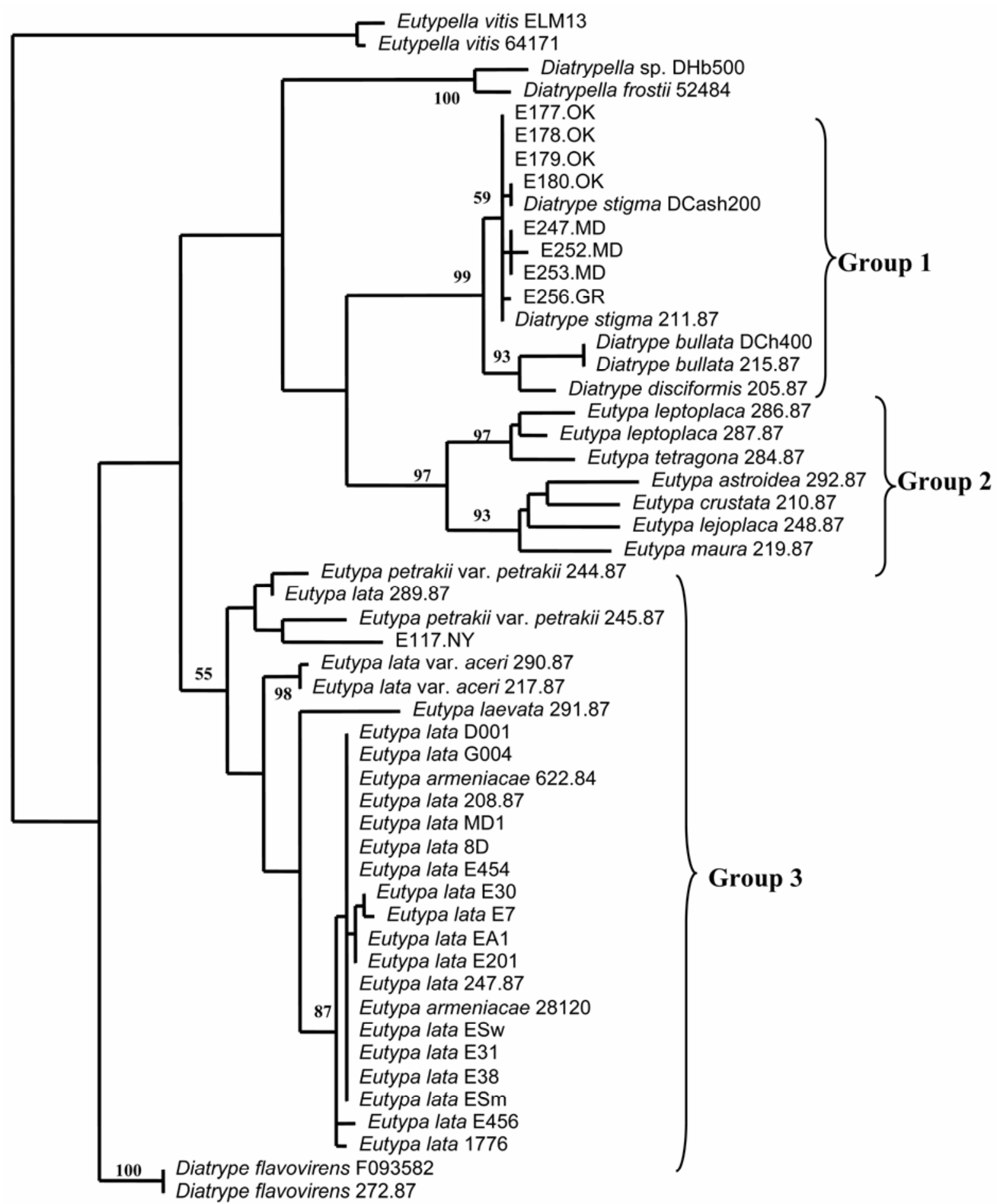

5 changes

Fig. 1. One of the 535 most parsimonious phylogenetic trees based on sequence differences in the internal transcribed spacer (ITS) $1 / 5.8 \mathrm{~S} / \mathrm{ITS} 2$ region. Clades that are supported by bootstrap analysis (1,000 replications) are indicated by numbers next to the clade (when more than $50 \%$ ). Tree length $=307$, consistency index $=$ 0.603 , retention index $=0.861$, and homoplasy index $=0.397$. 
conidia lengths ranging from $5.9 \pm 0.8$ to $7.5 \pm 0.5 \mu \mathrm{m}$. Finally, the conidia length of isolate E117.NY was measured at $19.4 \pm$ $3 \mu \mathrm{m}$. The conidia lengths of other diatrypaceous fungi already were published by Rappaz (33) and also are represented as a reference in Table 3. The conidia length of isolates in Table 3 was combined with the absence or presence of secondary metabolite production as determined in Table 2 in order to improve clarity in the results.

\section{DISCUSSION}

The phylogenetic reconstruction of individual and combined data sets support the results obtained by Acero et al. (1). The tree topology of the ITS region of several taxa placed in the family Diatrypaceae obtained by Acero et al. (1) distinguished nine groups within this family, from which groups 8, 3, and 6 correspond to groups 1,2, and 3, respectively, as presented in our analysis.

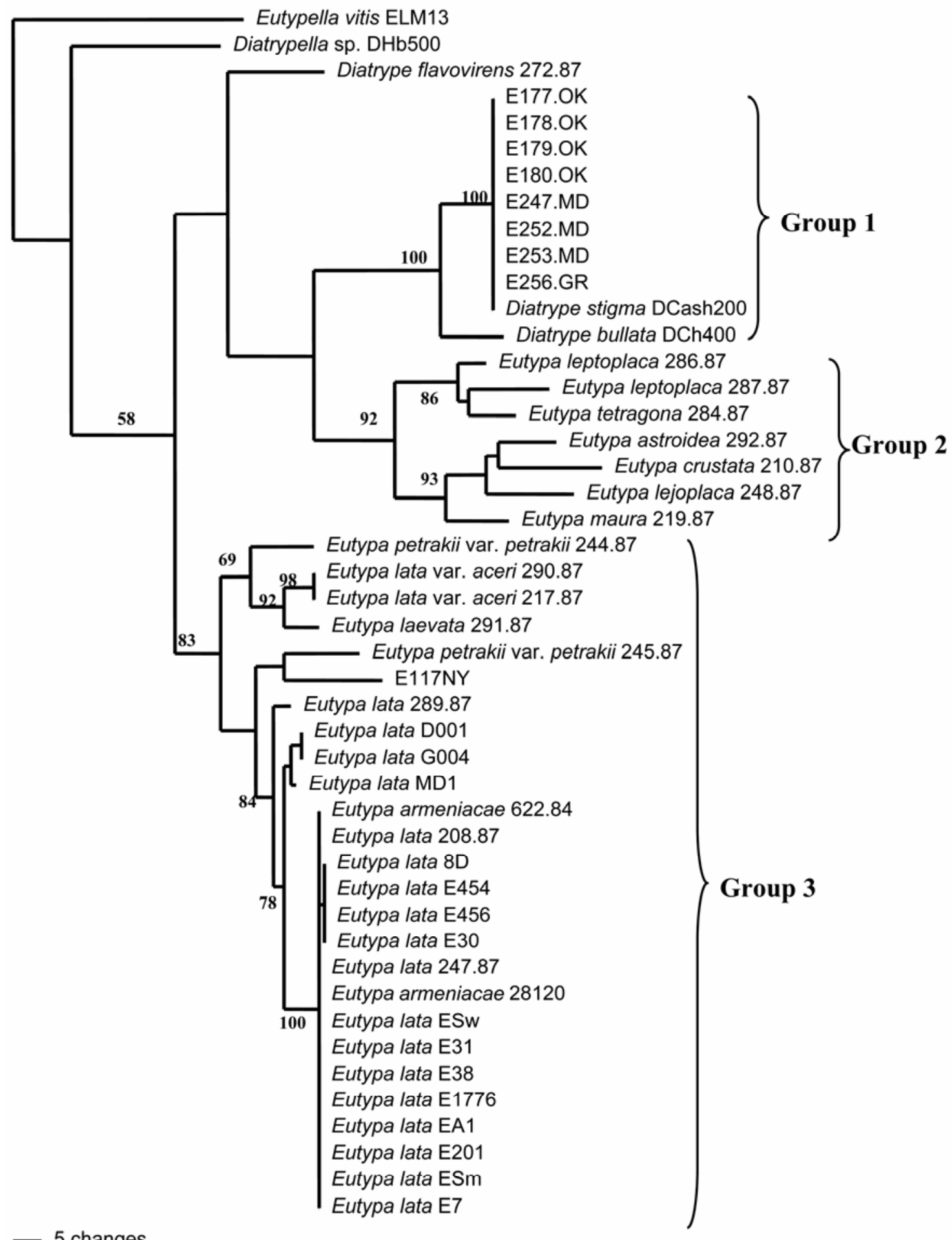

Fig. 2. One of the four most parsimonious phylogenetic trees based on sequence differences in the $\beta$-tubulin gene. Clades that are supported by bootstrap analysis $(1,000$ replications) are indicated by numbers next to the clade (when more than 50\%). Tree length $=404$, consistency index $=0.624$, retention index $=0.852$, and homoplasy index $=0.376$. 
Our data confirmed the polyphyletic origin of the genus Eutypa, but did not support recognition of E. lata and E. armeniacae as two distinct species as suggested by DeScenzo et al. (9). The group of eight isolates found on madrone, oak, and grape in California and referred to as E. lata in DeScenzo's work was shown to be related to D. stigma in our analysis (group 1). The attribution of names to Gallo's isolates collected in California was based on the morphology of the anamorph, and teleomorph when available, using the key of Glawe and Rogers $(16,17)$. Identification of fungi placed in the family Diatrypaceae is often problem- atic because of interspecific resemblance and intraspecific polymorphism of morphological characters. Phylogenetic analysis established by Acero et al. (1) did not support the morphological schemes used within the family Diatrypaceae for species delimitation. Moreover, the molecular analyses conducted by DeScenzo et al. (9) did not include other diatrypaceous fungi; therefore, they could not compare the grouping of their isolates with related taxa. Phylogenetic reconstruction using a combination of two genomic regions of several taxa placed in the family Diatrypaceae indicates that the eight Gallo isolates are referable to D. stigma.

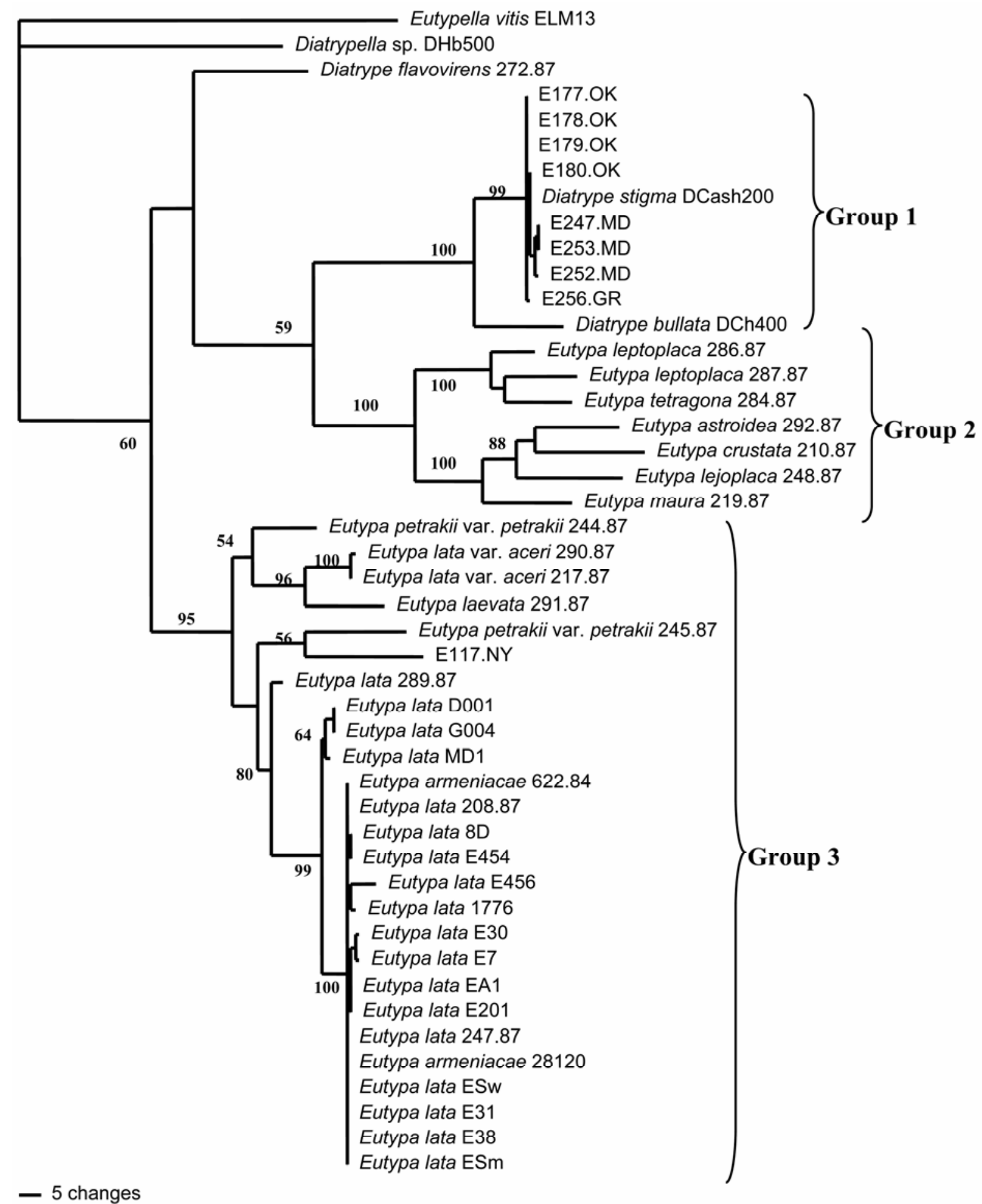

Fig. 3. One of the 260 most parsimonious phylogenetic trees based on sequence differences in the combined internal transcribed spacer (ITS) $1 / 5.8 \mathrm{~S} / \mathrm{ITS} 2$ region and $\beta$-tubulin gene. Clades that are supported by bootstrap analysis (1,000 replications) are indicated by numbers next to the clade (when more than $50 \%$ ). Tree length $=723$, consistency index $=0.609$, retention index $=0.833$, and homoplasy index $=0.391$. 
Glawe and Rogers (17) noticed that the specimens placed in the collection referable to $D$. stigma presented morphological polymorphisms and suggested that it could be separated into five morphological groups. Rappaz (34) also attributed two different species names $(D$. decortica and $D$. undulata) to the specimens that were morphologically distant from D. stigma sensu stricto. Based on our results, the conidia lengths of the eight Gallo isolates fit well with D. stigma group 3 as described by Glawe and Rogers (17) and D. stigma sensu stricto as described by Rappaz (34).

Four Eutypa spp. clustered in group 3 (E. lata, E. armeniacae, E. petrakii var. petrakii, and E. laevata). However, species delimitation within this group as established by Rappaz (33) using morphological characters was not totally supported by phylogenetic reconstruction. The grouping of the two E. petrakii var. petrakii isolates and the monophyly of $E$. lata were not demonstrated. A strong monophyletic clade that included most $E$. lata isolates as well as the two E. armeniacae isolates segregated from the rest of the taxa placed in group 3. E. lata and E. armeniacae were described in the literature as morphologically identical $(16,17$, 32,33 ), and our phylogenetic analyzes supported the synonymy of these two species. However, E. lata var. aceri (isolates 217.87 and 290.87) showed genetic divergence compared with the E. lata and E. armeniacae clade. Rappaz (33) also noted morphological differences between E. lata var. aceri and E. lata, such as pronounced aerial conidiogenesis and shorter conidia, but did not consider these specimens to be different species. Interestingly, the two E. lata var. aceri isolates are host specific to Acer spp. and were closely related to E. laevata, host specific to Salix spp. We propose that E. lata var. aceri should be renamed on the basis of the morphological and molecular features. The two taxa also differ in host range, with $E$. lata being a pathogen of many woody plants. The position of E. lata isolate 289.87 from Cratageus spp. is ambiguous, because it showed more nucleotide divergence than the other E. lata isolates and was placed outside the E. lata clade, but was the most closely related taxon. Rappaz noted distinctive morphological features of this isolate, such as formation of large pycnidia and production of aerial mycelium in rays. Based on these indications of morphological and molecular divergence, E. lata 289.87 also should not be considered as E. lata sensu stricto. Thus, only E. lata isolates 208.87 and 247.87 deposited at CBS should be regarded as authentic. Application of the biological species concept could clarify species delimitation within the Diatrypaceae family; however, to our knowledge, sexual reproduction of compatible isolates in vitro has not yet been possible.

The production of secondary metabolites by taxa clustered in group 3 suggested the synapomorphy of this character. None of the other taxa produced detectable quantities of the secondary metabolites analyzed, although E. leptoplaca (group 2) was found to produce different secondary metabolites in culture medium (N. Mahoney, unpublished data). To date, secondary metabolite production by specimens classified in the family Diatrypaceae has not been extensively investigated. However, research conducted in Xylariaceae, a sister family of Diatrypaceae (38), showed the production of a wide range of novel metabolites, including antibiotics and phytotoxic compounds (46). Whalley and Edwards (45) also determined that production of secondary metabolites in the family Xylariaceae was a constant and reliable feature, and that it could be used as an additional taxonomic character for species delimitation and to predict intra- and intergeneric associations. Biochemical data also have proven to be useful to reinforce species separation in other groups of fungi $(2,25,27)$. However, more research is yet needed to determine whether these chemotaxonomic schemes hold on within the family Diatrypaceae.

In our analysis, differences in qualitative and quantitative secondary metabolite production was observed among Eutypa spp. and E. lata isolates in group 3, ranging from high $(10$ to $40 \mu \mathrm{g} / \mathrm{ml})$ to no detectable levels. Several of these secondary metabolites have phytotoxic effect (19) and are considered virulence factors. Eutypine, for example, was reported to disrupt the functioning of mitochondria in Vitis vinifera cells $(10,12)$, but the sites targeted in planta by the other secondary metabolites have not yet been identified. However, our results indicated that eutypine was not the major secondary metabolite produced. These results also were supported by Mahoney et al. (20). Thus, the tolerance of grapevine cultivars to E. lata cannot be explained only by the detoxification of a single compound (i.e., eutypine) as previously supported $(12,18)$. The disparity in qualitative or quantitative production of secondary metabolites among E. lata isolates could partly explain their variation in virulence as previously observed on apricot (6) and grapevines (28,29), although such correlation has yet to be strongly established. E. lata is an outcrossing species presenting high genetic diversity $(29,30)$. Therefore, phenotypic differences, such as virulence, are expected to vary within $E$. lata populations. Consequently, delimitation of species based on pathogenic properties may not be appropriate within this group of fungi.

The results of this study also confirmed the occurrence of several diatrypaceous species on grapevines. As discussed above, D. stigma (E256GR) and Gallo isolate E117NY were recovered from grapevines. Trouillas et al. (43) also found the teleomorph of a Diatrype sp. on dead wood of grapes. A Diatrypella sp. also was recovered from wood cankers of grapevines (F. Trouillas, personal communication). Moreover, E. leptoplaca (42) and Cryptovalsa ampelina (24) were reported to be pathogenic on grapes. Ongoing studies are establishing the occurrence of these taxa within and in the vicinity of Californian vineyards. The presence of several related taxa on grapevines also suggests that precautions have to be taken for positive identification of the causal agent responsible for disease. Disease diagnosis commonly is done by isolating the organism from wood cankers on PDA medium; however, because of the morphological resemblance of species in this group of fungi in culture, misidentification can occur (35). Considerable work is still needed to establish proper species delimitations within the family Diatrypaceae, which will allow for more accurate identification of pathogens and development of more appropriate control strategies.

In conclusion, these results confirmed the polyphyletic origin of the genus Eutypa. Secondary metabolite production of isolates in the family Diatrypaceae showed good correlation with phylogenetic reconstruction. These data have proven to be useful to establish species recognition within this family of fungi, and to clearly confirm that $E$. lata and E. armeniacae do not represent different species but should continue to be regarded as synonymous.

\section{ACKNOWLEDGMENTS}

This work was supported by the American Vineyard Foundation and the Viticulture Consortium. We thank F. Trouillas (University of California, Davis), P. Larignon (INRA, Villenave D’Ornon, France), P. Cortesi (Instituto Di Pathologia Vegetale, Milano, Italy), M. Grease (Waite Research Precinct, Adelaide, Australia), S. Butterworth (Michigan State University) M. V. Carter (Australia), and A. Bolay (Switzerland) for providing fungal isolates used in this study; and T. Gordon and D. Rizzo (Department of Plant Pathology, University of California, Davis) for providing advice on the writing of this manuscript.

\section{LITERATURE CITED}

1. Acero, F. J., Gonzalez, V., Sanchez-Ballesteros, J., Rubio, V., Checa, J., Bills, G. F., Salazar, O., Platas, G., and Pelaez, F. 2004. Molecular phylogenetic studies of the Diatryapaceae based on rDNA-ITS sequences. Mycologia 96:249-259.

2. Andersen, D., Kroger, E., and Roberts, R. G. 2001. Chemical and morphological segregation of Alternaria alternata, A. gaisen and A. longipes. Mycol. Res. 105:291-299.

3. Bruns, T. D., White, T. J., and Taylor, J. W. 1991. Fungal molecular systematics. Annu. Rev. Ecol. Syst. 22:525-564. 
4. Carter, M. V. 1957. Eutypa armeniacae Hansf. \& Carter, sp. nov., an airborne vascular pathogen of Prunus armeniaca L. in Southern Australia. Aust. J. Bot. 5:21-35.

5. Carter M. V. 1991. The status of Eutypa lata as a pathogen. Monograph. Phytopathological Paper No. 32, International Mycological Institute, UK.

6. Carter, M. V., Bolay, A., English, H., and Rumbos, I. 1985. Variation in pathogenicity of Eutypa lata (=E. armeniacae). Aust. J. Bot. 33: 361-366.

7. Carter, M. V., Bolay, A., and Rappaz, F. 1983. An annotated list and bibliography of Eutypa armeniacae. Rev. Plant Pathol. 62:251-258.

8. Cenis, J. L. 1992. Rapid extraction of fungal DNA for PCR amplification. Nucleic Acids Res. 20:2380.

9. DeScenzo, R. A., Engel, S. R., Gomez, G., Jackson, E. L., Munkvold, G. P., Weller, J., and Irelan, N. A. 1999. Genetic analysis of Eutypa strains from California supports the presence of two pathogenic species. Phytopathology 89:884-893.

10. Deswarte, C., Canut, H., Klaebe, A., Roustan, J. P., and Fallot, J. 1996. Transport, cytoplasmic accumulation and mechanism of action of the toxin eutypine in Vitis vinifera cells. J. Plant Physiol. 149:336-342.

11. English, H., and Davis, J. R. 1978. Eutypa armeniacae in apricot: Pathogenesis and introduction of xylem soft rot. Hilgardia 46:193-204.

12. Fallot, J., Deswarte, C., Dalmayrac, S., Colrat, S., and Roustan, J.-P. 1997. Eutypa dieback of grapevine: Isolation of a molecule synthesized by Eutypa lata and toxic for grapevine. C. R. Acad. Sci. Ser. III: Sci. Vie 320:149-158.

13. Farris, J. S., Källersjö, M., Kluge, A. G., and Bult, C. 1995. Testing significance of incongruence. Cladistics 10:315-319.

14. Glass, N. L., and Donaldson, G. 1995. Development of primer sets designed for use with the PCR to amplify conserved genes from filamentous Ascomycetes. Appl. Environ. Microbiol. 61:1323-1330.

15. Glass, N. L., and Kuldau, G. A. 1992. Mating type and vegetative compatibility in filamentous Ascomycetes. Annu. Rev. Phytopathol. 30:201224.

16. Glawe, D. A., and Rogers, J. D. 1982. Observations on the anamorphs of six species of Eutypa and Eutypella. Mycotaxon 14:334-346.

17. Glawe, D. A., and Rogers, J. D. 1984. Diatrypaceae in the Pacific Northwest. Mycotaxon 20:401-460.

18. Guillen, P., Guis, M., Martinez-Reina, G., Colrat, S., Dalmayrac, S., Deswarte, C., Bouzayen, M., Roustan, J. P., Fallot, J., Pech, J. C., and Latche, A. 1998. A novel NADPH-dependent aldehyde reductase gene from Vigna radiata confers resistance to the grapevine fungal toxin eutypine. Plant J. 16:335-343.

19. Mahoney, N., Lardner, R., Molyneux, R. J. ,Scott, E. S., Smith, L. R., and Schoch, T. K. 2003. Phenolic and heterocyclic metabolite profiles of the grapevine pathogen Eutypa lata. Phytochemistry 64:475-484.

20. Mahoney, N., Molyneux, R. J., Leverett, R. S., Schoch, T. K., Rolshausen, P. E., and Gubler, W. D. 2005. Dying-arm disease in grapevines: Diagnosis of infection with Eutypa lata by metabolite analysis. J. Agric. Food Chem. 53:8148-8155.

21. Mauro, M. C., Vaillant, V., Tey-Rulh, P., Mathieu, Y., and Fallot, J. 1988. In vitro study of the relationship between Vitis vinifera and Eutypa lata (Pers.:Fr.) Tul. Demonstration of toxic compounds secreted by the fungus. Am. J. Enol. Vitic. 39:200-204.

22. McKemy, J. M., Glawe, D. A., and Munkvold, G. P. 1993. A hyphomycetous synanamorph of Eutypa armeniacae in artificial culture. Mycologia 85:941-944.

23. Molyneux, R. J., Mahoney, N., Bayman, P., Wong, R. Y., Meyer, K., and Irelan, N. 2002. Eutypa dieback in grapevines: Differential production of acetylenic phenol metabolites by strains of Eutypa lata. J. Agric. Food Chem. 50:1393-1399.

24. Mostert, L., Halleen, F., Creaser, M. L., and Crous, P. W. 2004. Cryptovalsa ampelina, a forgotten shoot and cane pathogen of grapevines. Australas. Plant Pathol. 33:295-299.

25. Mulè, G., Logrieco, A., Stea, G., and Bottalico, A. 1997. Clustering of trichothecene-producing Fusarium strains determined from $28 \mathrm{~S}$ ribosomal DNA sequences. Appl. Environ. Microbiol. 63:1843-1846.
26. Munkvold, G. P., Duthie, J. A., and Marois, J. J. 1994. Reductions in yield and vegetative growth of grapevines due to Eutypa dieback. Phytopathology 84:186-192.

27. O’Donnell, K., Cigelnik, E., and Casper, H. H. 1998. Molecular phylogenetic, morphological, and mycotoxin data support reidentification of the Quorn mycoprotein fungus as Fusarium venenatum. Fungal Genet. Biol. 23:57-67.

28. Peros, J.-P., and Berger, G. 1994. A rapid method to assess the aggressiveness of Eutypa lata isolates and the susceptibility of grapevine cultivars to Eutypa dieback. Agronomie 14:515-523.

29. Peros, J.-P., Berger, G., and Lahogue, F. 1997. Variation in pathogenicity and genetic structure in the Eutypa lata population of a single vineyard. Phytopathology 87:799-806.

30. Peros, J.-P., Jamaux-Despreaux, I., Berger, G., and Gerba, D. 1999. The potential importance of diversity in Eutypa lata and co-colonising fungi in explaining variation in development of grapevine dieback. Mycol. Res. 103:1385-1390.

31. Persoon, C. H. 1796. Observationes Mycologicae. 1:1-115. Lipsiae, Apud Petrum Phillippum Wolf.

32. Rappaz, F. 1984. Les éspèces sanctionnées du genre Eutypa (Diatrypacae, Ascomycetes). Etude taxonomique et nomenclaturale. Mycotaxon 20:567586.

33. Rappaz, F. 1987. Taxonomie et nomenclature des Diatrypacées a asques octosporées. Mycol. Helv. 2:285-648.

34. Rappaz, F. 1987. Taxonomie et nomenclature de Diatrype stigma, D. decortica et D. undulata (Diatrypaceae, Ascomycetes). Mycotaxon 30:209-219.

35. Rolshausen, P. E., Trouillas, F. P., and Gubler, W. D. 2004. Identification of Eutypa lata by PCR-RFLP. Plant Dis. 88:925-929.

36. Schmidt, C. S., Wolf, G. A., and Lorenz, D. 1999. Production of extracellular hydrolytic enzymes by the grapevine dieback fungus Eutypa lata. J. Plant Dis. Prot. 106:1-11.

37. Siebert, J. B. 2001. Eutypa: The economic toll on vineyards. Wines Vines 50-56.

38. Smith, G. J. D., Edward, C. Y., and Hyde, K. D. 2003. The Xylariales: A monophyletic order containing 7 families. Fungal Diversity 13:175-208.

39. Smith, L. R., Mahoney, N., and Molyneux, R. 2003. Synthesis and structure-phytotoxicity relationships of acetylenic phenols and chromene metabolites, and their analogues, from the grapevine pathogen Eutypa lata. J. Nat. Prod. 66:169-176.

40. Tey-Rulh, P., Philippe, I., Renaud, J. M., Tsoupras, G., De Angelis, P., Fallot, J., and Tabacchi, R. 1991. Eutypine, a phytotoxin produced by Eutypa lata the causal agent of dying-arm disease of grapevine. Phytochemistry 30:471-473

41. Thompson, J. D., Gibson, T. J., Plewniak, F., Jeanmougin, F., and Higgins, D. G. 1997. The CLUSTAL-X windows interface: Flexible strategies for multiple sequence alignment aided by quality analysis tools. Nucleic Acids Res. 25:4876-4882.

42. Trouillas, F. P., and Gubler, W. D. 2004. Identification and characterization of Eutypa leptoplaca, a new pathogen of grapevine in northern California. Mycol. Res. 10:1195-1204.

43. Trouillas, F. P., Rolshausen, P. E., and Gubler, W. D. 2001. Importance of Eutypa lata and occurrence of other diatrypaceous fungi in Northern Californian vineyards. (Abstr.) Phytopathology 91(suppl.):S89.

44. Tulasne, L. R., and Tulasne, C. 1863. Selecta Fungorum Carpologia. 2:1319. Parisiis, Imperatoris Jussu, In Imperiali Typographeo Excudebatur, Paris.

45. Whalley, A. J. S., and Edwards, R. L. 1995. Secondary metabolites and systematic arrangement within the Xylariaceae. Can. J. Bot. 73:S802S810.

46. Whalley, A. J. S. 1996. The xylariaceous way of life. Mycol. Res. 100:897-922

47. White, T. J., Bruns, T., Lee, S., and Taylor, J. 1990. Amplification and direct sequencing of fungi ribosomal RNA genes for phylogenetics. Pages 315-322 in: PCR Protocols. A Guide to Methods and Applications. Academic Press, San Diego, CA. 